\title{
Metropolis on the margins: talent attraction and retention to the St. John's city-region
}

\author{
JOSH LEPAWSKY \\ Department of Geography, Memorial University of Newfoundland, St. John's, Newfoundland, Canada, A1B 3X9 (e-mail: jlepawsky@mun.ca) \\ CHRYSTAL PHAN \\ Department of Geography, Memorial University of Newfoundland, St. John’s, Newfoundland, Canada, A1B 3X9 (e-mail: cmphan@mun.ca)
}

\section{ROB GREENWOOD}

Leslie Harris Centre, Memorial University of Newfoundland, St. John's, Newfoundland, Canada, AlC 557 (e-mail: robg@mun.ca)

The objective of this research is to examine the factors that influence the attraction and retention of creative and highly educated workers in a small-sized Canadian city. The study examines two hypotheses: that the social dynamics of city-regions constitute the foundations of economic success in the global economy; and, that talented, highly educated individuals will be attracted to those city-regions that offer a richness of employment opportunity, a high quality of life, a critical mass of cultural activity and social diversity. The hypotheses are explored through in-depth interviews with creative and highly educated workers, employers and intermediary organizations. The evidence from the interviews suggests mixed support for the hypotheses. In view of these findings, we contend that the specificities of place must be more carefully theorized in the creative class literature and be more carefully considered by policy-makers designing policies directed towards
Une métropole aux marges : l'attraction et la rétention des talents dans la ville-région de Saint-Jean, Terre-Neuve

L'objectif de cette recherche est d'identifier, parmi les facteurs d'attraction et de rétention d'une ville canadienne de petite taille, ceux qui exercent le plus d'influence sur la main-d'œuvre créative et bien formée. Deux hypothèses sont formulées dans le cadre de cette étude : la première est que la dynamique sociale dans les villes-régions est à la base du succès économique dans l'économie mondialisée. La seconde avance que les personnes talentueuses et bien formées viennent s'installer dans des villes-régions qui leur offrent un vaste éventail de possibilités d'emplois, une qualité de vie supérieure, un grand nombre d'événements culturels et de la diversité sociale. Afin d'explorer ces hypothèses, des entrevues en profondeur ont été effectuées auprès de représentants de la main-d'œuvre créative et bien formée, des employeurs et des organisations intermédiaires. Les résultats de ces entrevues n'ont pas été concluants. D'après les données obtenues, il est clair que le traitement des aspects particuliers des lieux dans la littérature sur la classe créative doit faire l'objet d'une théorisation plus poussée. Par 
attracting and retaining talented and highly educated workers.

Key words: human capital, creative class, Canada, Newfoundland, St. John's ailleurs, les décideurs doivent approfondir leurs connaissances des aspects particuliers des lieux avant que des politiques visant à attirer et retenir une main-d'cuvre talentueuse et bien formée ne soient conçues.

Mots clés : capital humain, classe créative, Canada, Terre-Neuve, Saint-Jean

national networks of places. St. John's exhibits what might be called 'metropolitan' or 'large' city characteristics because of its size and functional role relative to the provincial rural-urban system. On the other hand, the city-region's small size and isolation relative to larger and more connected national and international locations dampens its 'stickiness' (Markusen 1999) as a city-region for attracting and retaining talent. Our results from interviews suggest there is a dual character to St. John's-as both metropole and margin-that plays a critical role in its ability to attract and retain talent. What this means is that St. John's appears to be a staging ground for the province's home-grown creative and highly educated workers who envision future migration out of the province to further their careers. In interviews with creative and highly educated workers, employers and key intermediary organizations (e.g., labour associations, trade associations and immigration organizations), these relations of relative city size (framed by interviewees as 'smallness') and location (framed by interviewees as 'isolation' or 'disconnectedness') were noted, both explicitly and implicitly, as conditioning employment options and future career aspirations as well as the city-region's ability to attract and retain talent. In broad terms, what this means is that St. John's displays some features of 'urbanity'-for example, a thriving arts and cultural scene-disproportionate to its size and location. At the same time, due to St. John's smaller size and its disconnectedness relative to larger urban centres nationally and internationally, it also means that attracting and retaining talent is a significant challenge. We suggest that it is important for economic development plans premised on creative class concepts to carefully consider the role of relative size and location. Creative class concepts may not be applicable without significant modifications to account for 
the specificity of place (Johnstone and Lionais 2004).

\section{Methods}

This study is part of an on-going cross-national investigation of the social determinants of innovation in small, medium and large Canadian cityregions (Innovation Systems Research Network [ISRN] 2008). A total of 15 city-regions are being examined. Among the working assumptions of the study is that the absolute size of the cityregion is an important conditioning factor in the attraction and retention of highly educated and creative workers. The city-regions under investigation are divided into the following population size classes: small (100,000-249,000), medium $(250,000-999,999)$ and large $(1,000,000+)$.

The size classes defined for the ISRN study raise important issues for comparative analyses of the creative class hypothesis. It is relevant to note that studies that pay attention to city size as an important variable in conditioning the interactive relationships between cities, quality of place and the creative class do not use consistent statistical definitions of city size. This inconsistency may have important consequences in terms of drawing conclusions about correlative and causative relationships between city size and creative class location preferences. Though the ISRN project categorizes cities of 100,000249,000 as 'small', other recent Canadian studies on this topic classify cities quite differently. Sands and Reese (2008) call cities of 75,000350,000 'midsized' whereas Schimpf and Sereda (2001) and Schimpf (2008) classify cities over 100,000 as 'large' and those between 10,000 and 100,000 as 'small'. According to these various definitions of city size, St. John's fits all three size classes (small, medium and large). These kinds of differences in the classification of urban structure make comparative research that seeks to statistically test the validity of the creative class hypothesis difficult (Ferguson et al. 2007; Hansen and Niedomysl 2009). Given these definitional inconsistencies about absolute city-region size, we contend that qualitative approaches to perceptions about relative city size and location are also important measures of the interactions between city-regions and their ability to attract and retain talent.
The overall ISRN project examines hypotheses about the social dynamics of economic performance in Canada's city-regions divided into three themes: the social dynamics of innovation, the social foundations of talent attraction and retention and inclusive communities and civic engagement. Our article is focused on the theme of talent attraction and retention and investigates two hypotheses. First, that the social dynamics of city-regions constitute the foundations of economic success in the global economy. Second, that talented, highly educated individuals will be attracted to those city-regions that offer a richness of employment opportunity, a high quality of life, a critical mass of cultural activity and social diversity (e.g., Smith et al. 2005).

To investigate these hypotheses, we draw on 25 in-depth interviews with respondents classified into three categories defined in the methodology of the larger ISRN study (Wolfe 2006): (1) creative/highly educated workers/employees, (2) employers and (3) intermediary organizations (e.g., labour associations, trade associations and immigration organizations), where different sets of questions for each interview type are used (see Table 1 for interviewee demographics). ${ }^{1}$ Interviewees were selected from four broadly defined economic clusters identified by Spencer and Vinodrai (2006) as present in St. John's. These clusters are: (1) arts, media and culture, (2) health, (3) higher education and (4) maritime.

\footnotetext{
${ }^{1}$ Creative occupations, as defined for the ISRN study, follow Florida (2002a) and include: 'Senior management occupations; Specialist managers; Managers in retail trade, food and accommodation services; Other managers; Professional occupations in business and finance; Finance and insurance administrative occupations; Professional occupations in natural and applied sciences; Technical occupations related to natural and applied sciences; Professional occupations in health; Nurse supervisors and registered nurses; Technical and related occupations in health; Judges, lawyers, psychologists, social workers, ministers of religion and policy and program officers; Teachers and professors; Professional occupations in art and culture; and Technical occupations in art, culture, recreation and sport' (Spencer and Vinodrai 2006, 12). Bohemians are defined as artistic occupations and include: 'Authors, and writers; Producers, directors, choreographers and related occupations; Conductors, composers and arrangers; Musicians and singers; Dancers; Actors and comedians; Painters, sculptors and other visual artists; Photographers; Graphic designers and illustrators; Interior designers; Theatre, fashion, exhibit and other creative designers; Artisans and crafts persons and patternmakers, textile, leather and fur products' (Spencer and Vinodrai 2006, 12).
} 
Table 1

Interviewee type and demographics

\begin{tabular}{|c|c|c|c|c|c|}
\hline $\begin{array}{l}\text { Interview } \\
\text { number } \& \\
\text { pseudonym }\end{array}$ & $\begin{array}{l}\text { ISRN } \\
\text { cluster } \\
\text { type }\end{array}$ & $\begin{array}{l}\text { ISRN } \\
\text { interviewee } \\
\text { type }\end{array}$ & $\begin{array}{l}\text { Creative class } \\
\text { category } \\
\text { (Florida 2002a, } \\
\text { p. } 328 \text { ) }\end{array}$ & $\begin{array}{l}\text { Creative class } \\
\text { category } \\
\text { (Florida 2005, } \\
\text { p. 272) }\end{array}$ & Description \\
\hline$\# 1$ - Jacinta & $\begin{array}{l}\text { Higher } \\
\text { education }\end{array}$ & Employer & $\begin{array}{l}\text { Creative } \\
\text { professional }\end{array}$ & Manager & $\begin{array}{l}\text { Female, } 30 \text { s, Caucasian; }{ }^{\text {a }} \text { higher } \\
\text { education human resources manager }\end{array}$ \\
\hline \#2 - Ron & Other & Intermediary & $\begin{array}{l}\text { Creative } \\
\text { professional }\end{array}$ & Manager & $\begin{array}{l}\text { Male, } 60 \text { s, Caucasian; president of trade } \\
\text { association }\end{array}$ \\
\hline \#3 - Lawrence & Health & Intermediary & $\begin{array}{l}\text { Creative } \\
\text { professional }\end{array}$ & Manager & $\begin{array}{l}\text { Male, } 60 \text { s, Caucasian; director of health } \\
\text { research organization }\end{array}$ \\
\hline \#4 - Bonny & Other & Intermediary & $\begin{array}{l}\text { Creative } \\
\text { professional }\end{array}$ & Manager & $\begin{array}{l}\text { Female, } 60 \text { s, Caucasian; director of civil } \\
\text { society immigration group }\end{array}$ \\
\hline \#5 - Wilson & Maritime & Employer & $\begin{array}{l}\text { Creative } \\
\text { professional }\end{array}$ & Manager & $\begin{array}{l}\text { Male, } 50 \text { s, Caucasian; president of } \\
\text { offshore industries engineering firm }\end{array}$ \\
\hline \#6 - Michael & $\begin{array}{l}\text { Arts, media \& } \\
\text { culture }\end{array}$ & $\begin{array}{l}\text { Highly educated/ } \\
\text { creative worker }\end{array}$ & Supercreative core & Artist & Male, 20s, Caucasian; musician \\
\hline \#7 - Jason & $\begin{array}{l}\text { Arts, media \& } \\
\text { culture }\end{array}$ & $\begin{array}{l}\text { Highly educated/ } \\
\text { creative worker }\end{array}$ & Supercreative core & Artist & Male, 20s, Caucasian; filmmaker \\
\hline \#8 - Sarah & $\begin{array}{l}\text { Arts, media \& } \\
\quad \text { culture }\end{array}$ & $\begin{array}{l}\text { Highly educated/ } \\
\text { creative worker }\end{array}$ & Supercreative core & Artist & Female, 20s, Caucasian; filmmaker \\
\hline$\# 9$ - Betty & Health & Intermediary & $\begin{array}{l}\text { Creative } \\
\text { professional }\end{array}$ & Manager & $\begin{array}{l}\text { Female, } 40 \text { s, Caucasian; president of } \\
\text { labour union }\end{array}$ \\
\hline$\# 10$ - Frank & Maritime & $\begin{array}{l}\text { Highly educated/ } \\
\text { creative worker }\end{array}$ & $\begin{array}{l}\text { Creative } \\
\text { professional }\end{array}$ & Manager & $\begin{array}{l}\text { Male, } 50 \text { s, Caucasian; business } \\
\text { development manager of offshore oil \& } \\
\text { gas engineering firm }\end{array}$ \\
\hline \#11 - Richard & Maritime & Employer & $\begin{array}{l}\text { Creative } \\
\text { professional }\end{array}$ & Manager & $\begin{array}{l}\text { Male, } 50 \mathrm{~s} \text {, Caucasian; general manager } \\
\text { of offshore oil \& gas engineering firm }\end{array}$ \\
\hline \#12 - Hamish & $\begin{array}{l}\text { Higher } \\
\quad \text { education }\end{array}$ & $\begin{array}{l}\text { Highly educated/ } \\
\text { creative worker }\end{array}$ & Supercreative core & Scientist & $\begin{array}{l}\text { Male, } 30 \text { s, Caucasian; aquaculture PhD } \\
\text { student }\end{array}$ \\
\hline \#13 - Sally & Other & Employer & $\begin{array}{l}\text { Creative } \\
\text { professional }\end{array}$ & Professional & $\begin{array}{l}\text { Female, } 40 \text { s, Caucasian; public relations } \\
\text { consultant }\end{array}$ \\
\hline \#14 - Tom & Other & $\begin{array}{l}\text { Highly educated/ } \\
\text { creative worker }\end{array}$ & $\begin{array}{l}\text { Creative } \\
\text { professional }\end{array}$ & Manager & $\begin{array}{l}\text { Male, } 40 \text { s, Caucasian; provincial } \\
\text { government department of tourism, } \\
\text { culture and recreation }\end{array}$ \\
\hline \#15 - Gwynn & $\begin{array}{l}\text { Arts, media \& } \\
\text { culture }\end{array}$ & $\begin{array}{l}\text { Highly educated/ } \\
\text { creative worker }\end{array}$ & Supercreative core & Artist & Female, 40s, Caucasian; musician \\
\hline \#16 - Brenda & Other & Intermediary & $\begin{array}{l}\text { Creative } \\
\text { professional }\end{array}$ & Manager & $\begin{array}{l}\text { Female, } 40 \mathrm{~s} \text {, Caucasian; provincial } \\
\text { government department of business }\end{array}$ \\
\hline \#17 - Mark & Other & Employer & $\begin{array}{l}\text { Creative } \\
\text { professional }\end{array}$ & Manager & $\begin{array}{l}\text { Male, } 50 \text { s, Caucasian; bank vice } \\
\text { president }\end{array}$ \\
\hline \#18-Ron & Other & Employer & $\begin{array}{l}\text { Creative } \\
\text { professional }\end{array}$ & Manager & Male, 50s, Caucasian; bank director \\
\hline \#19- Karim & Maritime & $\begin{array}{l}\text { Highly educated/ } \\
\text { creative worker }\end{array}$ & Supercreative core & Professional & Male, 30s, Asian; naval architect \\
\hline \#20 - Laura & Other & Employer & $\begin{array}{l}\text { Creative } \\
\text { professional }\end{array}$ & Professional & $\begin{array}{l}\text { Female, } 40 \text { s, Caucasian; Environmental } \\
\text { consultant }\end{array}$ \\
\hline \#21 - Paul & $\begin{array}{l}\text { Arts, media \& } \\
\text { culture }\end{array}$ & $\begin{array}{l}\text { Highly educated/ } \\
\text { creative worker }\end{array}$ & Supercreative Core & Artist & Male, 20s, Caucasian; musician \\
\hline \#22 - Nick & Other & Intermediary & $\begin{array}{l}\text { Creative } \\
\text { professional }\end{array}$ & Manager & $\begin{array}{l}\text { Male, } 40 \text { s, Caucasian; federal } \\
\text { government accounts manager }\end{array}$ \\
\hline \#23 - Bob & Other & $\begin{array}{l}\text { Highly educated/ } \\
\text { creative worker }\end{array}$ & $\begin{array}{l}\text { Creative } \\
\text { professional }\end{array}$ & Professional & $\begin{array}{l}\text { Male, } 50 \text { s, Caucasian; business } \\
\text { consultant }\end{array}$ \\
\hline
\end{tabular}


Table 1

Continued.

\begin{tabular}{lccccc}
\hline $\begin{array}{l}\text { Interview } \\
\text { number } \& \\
\text { pseudonym }\end{array}$ & $\begin{array}{c}\text { ISRN } \\
\text { cluster } \\
\text { type }\end{array}$ & $\begin{array}{c}\text { ISRN } \\
\text { interviewee } \\
\text { type }\end{array}$ & $\begin{array}{c}\text { Creative class } \\
\text { category } \\
\text { (Florida 2002a, } \\
\mathbf{p . ~ 3 2 8 )}\end{array}$ & $\begin{array}{c}\text { Creative class } \\
\text { category } \\
\text { (Florida 2005, } \\
\mathbf{p . ~ 2 7 2 )}\end{array}$ & Description \\
\hline \#24-Jane & Maritime & Intermediary & $\begin{array}{c}\text { Creative } \\
\text { professional } \\
\text { Creative } \\
\text { professional }\end{array}$ & Manager & $\begin{array}{c}\text { Female, 40s, Caucasian; board member of } \\
\text { trade association } \\
\text { Male, 50s, Caucasian; board member of trade } \\
\text { association }\end{array}$ \\
\hline
\end{tabular}

${ }^{a}$ As part of the ISRN interview protocol, respondents were asked the following open-ended question: 'How would you describe your ethnic identity?' 24 of our 25 interviewees described themselves as 'Caucasian' and one interviewee described himself as 'Asian'. These were the respondents' own descriptions, not predetermined categories from which they were asked to choose. By reporting these descriptions as part of the interviewee demographics, we are not construing 'race' as a biological essence. Instead, we understand race as a discursive construct (see Peake and Ray 2001) and discuss its importance with respect to the subject position assumed by creative class theory (more generally, see Kobayashi and Peake 2000).

An additional 'other' category includes interviewees/organizations relevant to the broader ISRN study of social foundations of talent attraction and retention but who are outside the four cluster categories relevant for St. John's. This 'other' category includes, for example, professional consultants, government institution employees and commercial bankers, but those who are not employed in any of the four St. John's clusters.

Potential interviewees were initially recruited by e-mail using publicly available contact information from industry membership directories. $^{2}$ Those who agreed to participate were interviewed according to one of the three ISRN categories (creative/highly educated workers/ employees; employers of creative/highly educated workers/employees or intermediary organizations). At the conclusion of each interview participants were asked to suggest names and contact information for additional potential participants. The recruitment of participants was done with an eye to developing an informationrich interview dataset. We continued to contact potential participants and conduct interviews until we reached theoretical saturation, that is, the point at which the ideas discussed by interviewees in response to interview questions began to recur (Crang and Cook 2007).

Our discussion of results is divided into two sections. The first is devoted to the interview

\footnotetext{
${ }^{2}$ The East Coast Canada Oil and Gas membership directory; the Newfoundland and Labrador Environmental Industry Association directory and Newfoundland and Labrador Export directory.
}

talk of members of the super creative core (Florida 2002a) in their roles as creative and highly educated workers. The second section is devoted to that of creative professionals (Florida 2002a) in their roles as employers of creative and highly educated workers or intermediary organizations. While we highlight and discuss the interview talk of particular individuals, the range of discourses we encountered in participants' interview talk span four themes that were common to all 25 participants. These themes emerged out of participants' responses to the sets of interview questions designed for the broader ISRN study. These questions address respondents' social background and employment history as well as their perceptions of the attractiveness of the relevant city-region and factors that enhance or challenge the city-region's ability to attract and retain talent. The four themes common to our interviews are, first, the importance of relative citysize, (dis)connectedness and mobility; second, the importance of social networks for enhancing economic security and creativity; third, loyalty to place in spite of a perception of greater economic attractiveness and creative 'buzz' being available elsewhere and fourth, the lack of perceived links between St. John's as a city-region and the creativity of highly educated and creative professionals.

\section{Literature Review}

Creative class theory proposes that regional economic growth is driven by the location choices 
of a group of people that 'engage in complex problem solving that involves a great deal of independent judgement and requires high levels of education or human capital' (Florida 2002a, 8 ). Members of this class share a common economic identity defined by occupational categories (e.g., Florida 2002b, 2002c, 2005, 2008; Stolarick and Florida 2006; Florida et al. 2008; Martin and Florida 2009). The creative class is divided into two broad groups, the super creative core (e.g., computer and mathematical occupations, sciences, education and arts) and creative professionals (e.g., management occupations, business and financial operations, legal, healthcare and high-end sales) (Florida 2002a). The location decisions of the creative class are determined by a co-mingling of attributes that Florida (2002a) calls 'quality of place'. These attributes include the presence of thick labour markets (meaning high quantity, quality and diversity of employment options), lifestyle amenities (e.g., parks, running trails, nightlife), possibilities for social interaction in 'third places' such as cafés and book stores that are neither home (first place) nor work (second place), diversity (e.g., ethnicity, age, sexuality) and authenticity (e.g., a distinctive music 'scene', historic-built landscapes and demographic mixture) (Florida 2002a, 228-229).

While creative class theory does not argue that amenities are a perfect substitute for wages and employment, it does claim that a key shift has occurred: people are "not slavishly following jobs to places' (Florida 2002a, 223), rather firms and jobs are locating, relocating or being created where the talent is. A key recommendation of creative class theory is that regions should make or enhance quality of place characteristics that attract and retain the creative class to stimulate economic growth. It is a case of attracting and retaining talented people, rather than attracting businesses per se.

The creative class hypothesis and variations on it have garnered much recent attention because of the potential to inform economic development policy. By measuring creative indicators (e.g., Deller et al. 2001; Gertler 2003; Beugelsdijk 2007), studying regions that demonstrate creative capital's capacity for economic growth (e.g., Lloyd 2002, 2004; Currid 2006) and exploring the lifestyle propensities of the creative class (e.g., Bridge 2007; Danyluk and Ley 2007; McGrana- han and Wojan 2007), officials hope to learn how to harness creativity and innovation for regional economic growth and competitiveness. Although most of these studies are American-based, academic and government researchers are beginning to expand the scope of the creative class concept to include Canadian cities (Schimpf and Sereda 2001; Donald and Morrow 2003; Wolfe and Gertler 2004; Rantisi and Leslie 2006; Rantisi et al. 2006; Stolarick and Florida 2006; Sands and Reese 2008; Schimpf 2008; Florida et al. 2010).

While the reputation of creative class theory grows in popular and policy discourses (e.g., Ashbrook 2009; Florida 2009), it has been subject to pointed academic debate. A recent thread of critical literature is particularly important for the arguments we make here about the role of the relative size and location of St. John's. In a set of large, cross-national studies examining the distribution of the creative class and regional development in Europe, questions have been raised about the effect of strong urban hierarchies on the location decisions of the creative class (see Hansen and Niedomysl 2009). These studies show mixed support for the propositions of creative class theory (Asheim and Hansen 2009). Boschma and Fritsch (2009), for example, wonder whether the different results they obtain for distributions of the creative class in Germany, the Netherlands, England and Wales reflect the particularities of those countries' urban patterns. Related studies (e.g., Asheim and Hansen 2009; Hansen and Niedomysl 2009; Lorenzen and Andersen 2009) point to similar mixed results and also suggest that in countries with strong urban hierarchies (e.g., Sweden), where only a few large city-regions dominate the national urban system, there may be confounding effects between the rank and centrality of these dominant urban regions and the co-presence of the growth factors of talent, technology and tolerance proposed by creative class theory. For example, Lorenzen and Andersen (2009, 365) find that the distribution of the creative class across 444 city-regions in eight European countries follows a rank-size rule that is different from the total population and favours larger centres to the extent that the creative class 'is less attracted to the smallest cities than the total population'. But such systematic relationships between the centrality of city-regions and the presence of the 
creative class raise uncertainties about causes and effects. Thus, given the results of their examination of 500 regions across seven European countries, Boschma and Fritsch are left wondering, 'do successful regions create, retain, and attract creative capital, or vice versa, or, again, is it some combination of both?' $(2009,419)$.

Like some European and Scandinavian countries, Canada also has a pronounced urban hierarchy where a small number of large cityregions dominate the national space economy. Important differences between the urban history and dynamics of Canadian versus US cities suggest reasons to be cautious about importing creative class strategies to Canadian urban economic development policy. For instance, the size and density differences that exist between Canadian and US cities are of particular concern (see Bunting 2004). US-based creative class research has categorized the US urban system into four peer groups: regions of $\geq 1,000,000 ; 500,000-1,000,000 ; 250,000-500,000$ and $\leq 250,000$ (Florida 2005). In contrast to the US with 75 metropolitan regions of $\geq 1,000,000$ (United States Census Bureau 2009), Canada only has six metropolitan regions of this size (Statistics Canada 2009a). Thus Canada has a pronounced urban hierarchy creating a situation that may confound such factors as absolute city size and the quality of place characteristics theorized as relevant to the location decisions of the creative class (cf. Hansen and Niedomysl 2009).

Other critiques of creative class theory have questioned its consistency and empirical rigour. For example, Markusen (2006) notes a tendency to conflate creativity with high levels of education and that the occupational categories of the creative class exclude many occupations where 'creativity' is at work, while including categories that are not intuitively creative occupations (e.g., insurance adjusters, actuaries, tax collectors). Other critics are sceptical of what they argue are overly hasty leaps from correlation to causality between the supposed entrepreneurial acumen of the creative class and a vibrant urban economy (Scott 2006; Storper and Manville 2006; Thomas and Darnton 2006; Wojan et al. 2007; Hansen and Niedomysl 2009). Still others question creative class theory in terms of its assumptions about class formation and class politics.
Markusen (2006) doubts that the varieties of occupations lumped together in statistical studies of the creative class (e.g., insurance adjusters, actuaries, tax collectors, lawyers, engineers, musicians, writers and dancers) can be logically assumed to share a class identity. More pointedly, Peck (2005) contends that the reason creative class theory has gained such popularity in policy circles is that it helps to depoliticize the reproduction and expansion of status-quo capital accumulation strategies while side-stepping the issues of social inequality that such accumulation creates (see also Barnes et al. 2006; McCann 2007; Donegan and Lowe 2008). Despite these criticisms, cities worldwide are adopting creative city strategies (Scott 2006; Wong and Bunnell 2006; Clifton 2008).

\section{Provincial and National Context}

Conventional wisdom suggests that most urban centres in Canada were restructuring to accommodate the 'knowledge economy' beginning in the 1970s, shifting from manufacturing and industry to a service-based economy (Bunting and Filion 2006; Wernerheim and Sharpe 2006). But the geographies of this shift have been highly uneven within national urban systems such as Canada's, where inter- and intraurban variation is the norm. Despite the broad shift to a 'service economy', economic and political change in Newfoundland continues to be shaped by resource capitalists and a staples economy (Innis 1940; Summers 2001; Roy et al. 2006; Locke 2007). As the provincial capital and largest city-region, St. John's urban fabric is shaped by the political economy of extractive resource industries, tempered by the city's function as administrative metropole for the province. Except for a few select urban centres linked to St. John's along the TransCanada highway, the province's urbanrural network is experiencing dramatic population loss, a factor especially prevalent in the province's outport peripheries (see Figure 1).

In work related to the ISRN project characterizing the 15 city-regions under study, Spencer and Vinodrai (2009) calculate location quotients (LQs) that show St. John's is less diverse in relation to Canada as a whole in terms of ethnicity and place of birth (LQ of 1.2 for St. John's 


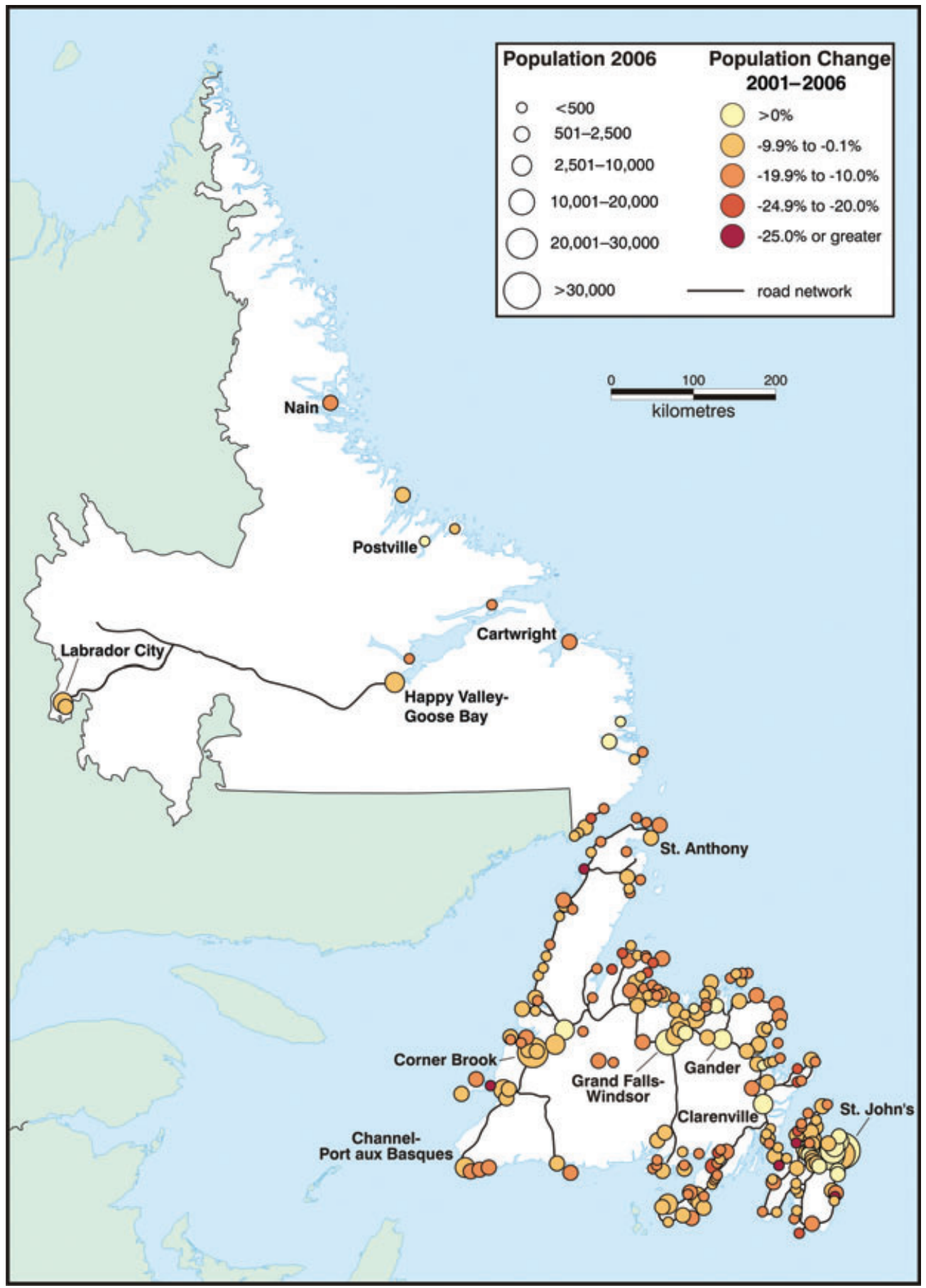

Figure 1

Population change in Newfoundland and Labrador, 2001-2006

The Canadian Geographer / Le Géographe canadien 54, no 3 (2010) 
population born in Canada and $<0.2$ for population born outside Canada). However, the cityregion's population exceeds national averages in creative occupations at 38.6 percent versus 33.2 percent for Canada. ${ }^{3}$ Furthermore, in a recent study the 'A1C' postal code of downtown St. John's was found to have an artistic concentration four times higher than the national average and the second densest concentration of artists in Atlantic Canada after Halifax harbour south (Hill Strategies 2005).

Between 2001 and 2006, St. John's as a whole increased its population by 4.7 percent, to 181,115 (Spencer and Vinodrai 2009). The labour market dominance of the Newfoundland and Labrador capital city extends even further on the province's Avalon Peninsula. Over 40 percent of the province's population now resides in communities within St. John's commuting area (Simms 2009) (see Figure 2). In the wake of fisheries closures and restructuring, the closure of two paper mills and the ongoing rural to urban and urban-adjacent shift, St. John's dominates the province's economy more than ever and is a staging ground for migration out of the province (see Figure 3). Significant wealth is still generated from the fishery and mining continues to be a major source of wealth creation on the Island and in Labrador. Most of all, however, the province's real GDP is now dominated by oil production, accounting for almost 30 percent in 2007 (Stantec 2009). Ironically, and cruelly for rural communities, oil and gas fields have been found primarily on the Grand Banks, closest to St. John's. The province's political, educational and service centre is now also the home of the largest resource sector.

\section{Results}

In what follows, we discuss the key themes that arose in interviews with highly educated/creative

\footnotetext{
${ }^{3}$ Though the calculations by Spencer and Vinodrai (2009) compare the St. John's CMA to Canada as a whole, metropolitan Canada accounts for approximately 80 percent of the Canadian population. Comparing the St. John's CMA only to the Canadian metropolitan population would only further accentuate the differences Spencer and Vinodrai's calculations indicate.
}

workers and with employers of highly educated/creative workers and intermediary organizations (as shown in Table 1). Though we focus on the responses of particular individuals, the themes we discuss arose in all 25 interviews. These key themes are, first, relative city-size, (dis)connectedness and mobility. The latter theme emerged in participants' interview talk where references were made to city size and location characteristics of St. John's in ways that suggest they perceive it to be large in relation to the province's rural-urban system, yet small in relation to national and international urban systems; connected in terms of high-quality (rather than high-quantity) social networks, yet disconnected from places outside the province and that taken together, these characteristics of relative city size and (dis)connectedness condition the mobility decisions of highly educated/creative workers in both positive and negative ways. A second theme that emerged across all interviews is the importance of social networks for enhancing economic security and creativity. A third theme was an elaboration of a distinct loyalty to place, in spite of greater economic attractiveness and creative 'buzz' being available elsewhere. The latter is the one theme where distinctive differences could be found between those participants who were born and raised in Newfoundland and in-migrants. This theme illuminated an insider/outsider dynamic that all participants spoke to, but framed differently, in relation to their own positionality as 'Newfoundlander' or 'from away'. A fourth theme that emerged was the expression of a lack of perceived links between St. John's as a city-region and the creativity of highly educated and creative professionals. In each of these themes, the interviewees perceived relative city size and location of St. John's to be conditioning factors-both positive and negative-in their decisions to be based here and their future career aspirations.

\section{Highly educated/creative workers}

We begin with a discussion of themes arising in interviews with highly educated and creative workers. In each case, when asked about movement between sectors or occupations and future career aspirations, interviewees spoke 


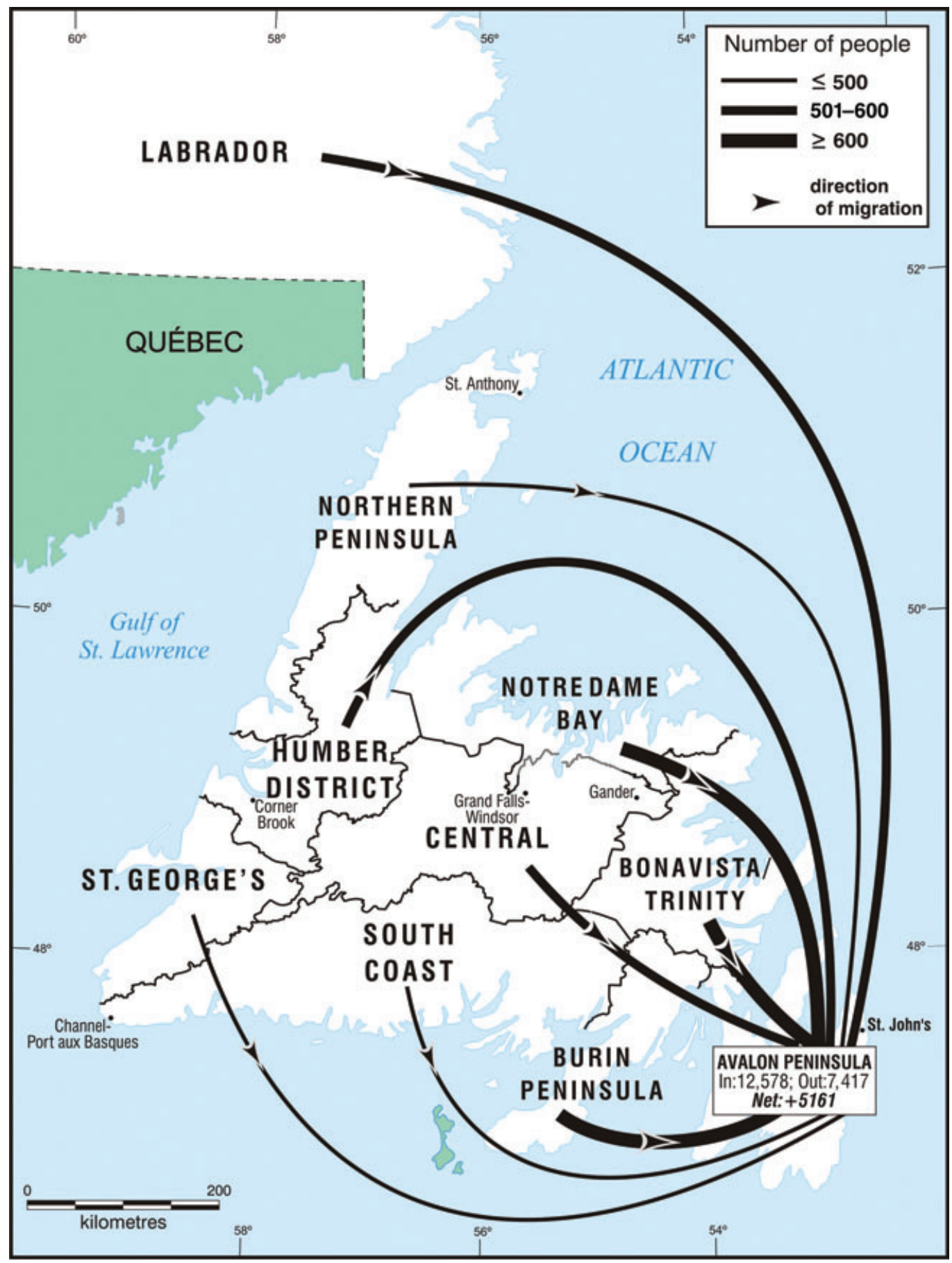

Figure 2

Net intraprovincial migration for Newfoundland and Labrador, 2001-2006 


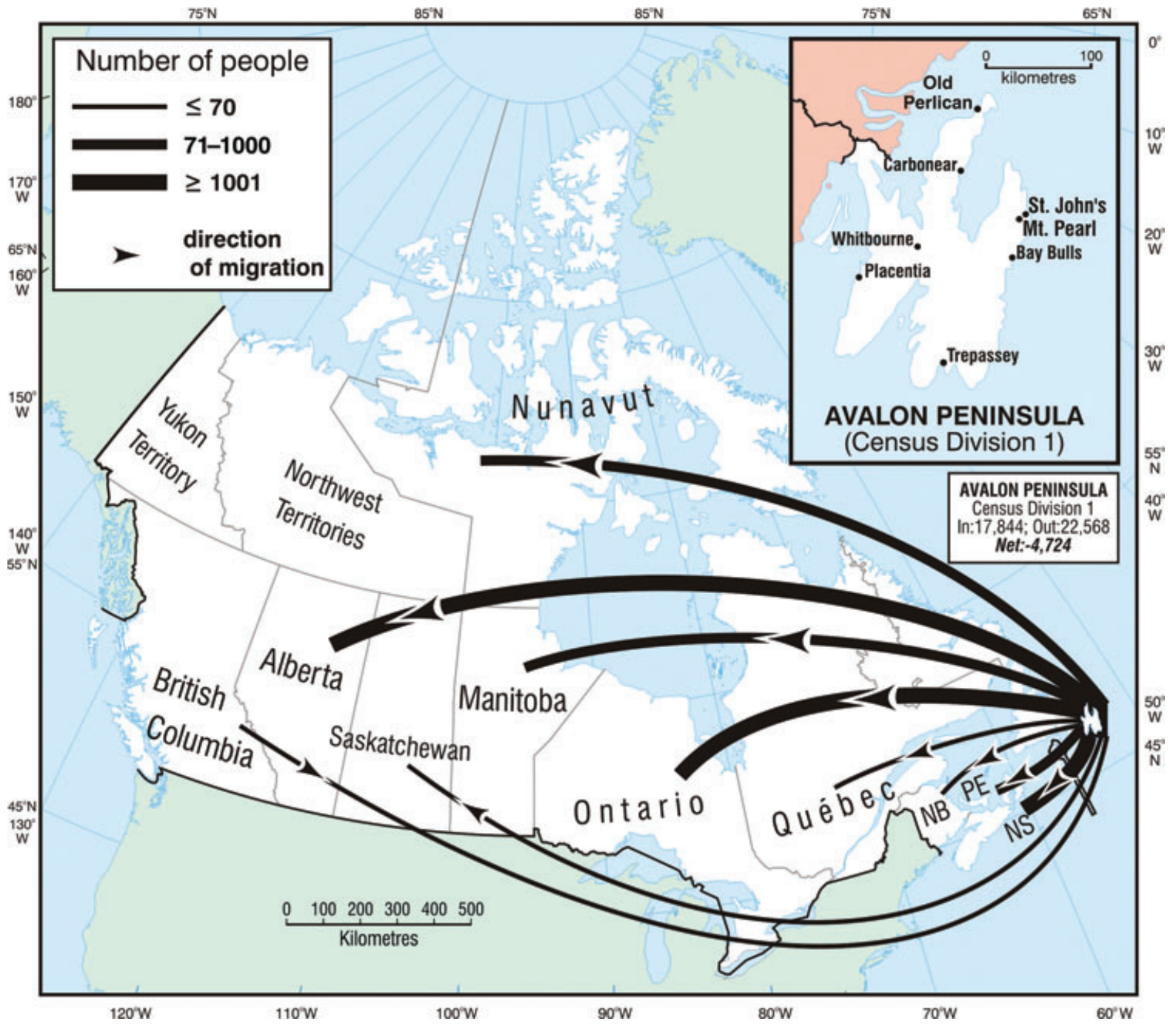

Figure 3

Net interprovincial migration for the Avalon Peninsula (Census Division 1), 2001-2006

to the issue of relative city-size, location and (dis)connectedness as significant factors conditioning their past employment experiences and future career aspirations.

When asked about mitigating the risks of unemployment, interviewees emphasized how characteristics of place condition the strength and density of both family and social networks. For example, Michael, a successful musician with a degree in sociology, told us:
I just have a lot of family here. I mean, my mom and dad are here and they helped me out big time; and, obviously, I just know a lot of people. There's just like a big social network, so getting a job really wouldn't be that hard. Just, you know, call my uncles and aunts and, I mean, you know, they have businesses or have brothers who own businesses. I mean, it's just such an incredible network of people. I mean, I could probably get a job in an hour. . 
Michael suspects, though he is not certain, that city size and what he refers to as the 'culture' and the 'isolation' of St. John's are key factors in conditioning the important social networks that reduce the risk of losing one's job. For Michael, these social networks were less something to do with the city's economy, than with its relative size and location:

[I]t's just a small sort of city where you know everybody, and there's just these social ties to so many different sectors and so many different businesses. I don't know if it's specific to this place because of the culture or because of the isolation, but everyone seems to be just incredibly interconnected, and, you know dozens of people who own things or hire people and put in a word for you, you know.

Within Michael's response, then, we do get a sense that some of the factors suggested in the creative class literature are at play in St. John's case. For example, Michael draws attention to qualities of place and their influence on the strength and density of social relationships. But there are also important nuances hinted at in Michael's response. For example, Michael identifies city size as at least one probable factor explaining the strength and density of social networks that mitigate against the risks of job loss. Yet, it is his perception of St. John's being a small city that is key to the character of these networks. In the literature, the tendency is to associate increases in the density of social networks with larger city populations-in simplistic terms: more people, more networks. Michael's response at least hints at a potentially important point: that the quality of social networksnot just the number of them-is important and that the relative smallness of St. John's can play a positive role in facilitating strong, dense social networks that mitigate against the risks of job loss. This theme of 'smallness' and dense social networks recurred in our interviews. It suggests the importance of thinking critically about the assets of relatively small cities and to understand that 'smallness' should not simply be seen as a liability in terms of attracting and retaining creative and highly educated individuals (cf. Doloreux and Dionne 2008).

Michael also draws attention to what he calls the 'culture' of St. John's and its 'isolation' as two other factors that condition the social networks that mitigate against job loss. Our interviews with Michael and others suggest that 'culture' here means a strong, tangible sense of mutual support in the artistic community broadly-and in the music and film industries, specifically-that helps individual workers overcome the precarious nature of artistic employment and especially the boom-bust character of the film industry in the province. Michael perceives these practices of mutual support to be strengthened by the isolation of St. John's, where, because of the relative disconnectedness of the city-region provincially, nationally and internationally, a culture of mutual support is a survival tactic for workers in the cultural industries.

Jason, a successful filmmaker with a degree in fine arts, also pointed to what he sees as St. John's small size as being an asset for mitigating the risk of job loss, but he continued by saying: 'You know, sometimes it's really busy and everyone works, and then there's a lot of periods in between when people don't; and they're still, one way or another through places like Newfoundland Independent Film Co-op, or just independent groups that are formed, people find a way to get work made regardless'. For Jason, as with Michael, the strength of mutual support networks in the artistic community is crucial. Jason and other filmmakers manage to get work done through mutual support networks that help further their careers as filmmakers. There are significant periods when paid work in the industry is scarce, but Jason is still able to make important progress in terms of his career by building his body of work thanks in part to a culture of volunteerism in the film community.

Sarah, another filmmaker with a fine arts degree, also drew attention to the importance of the strength and density of social networks that are important in terms of mitigating the risks of job loss:

What's so great about this place is, you know, you become part of this really small community and it's really wonderful and everybody knows each other and, you know, everybody supports each other [...] the community that I work in is relatively small and close-knit, so there's a core group of people who always work on set ... But

The Canadian Geographer / Le Géographe canadien 54, no 3 (2010) 
in terms of social networks, I mean everybody is extremely supportive of one another because everybody knows each other, and so everybody is always willing to help out on smaller projects.

As in the cases of Michael and Jason, what appears to be important from Sarah's point of view is the small size of St. John's. Its relatively small size plays an important and positive role in creating a close-knit, supportive social network that helps overcome the precarious, boom-bust character of the film industry.

Not only do Michael, Jason and Sarah suggest that small city size can be an asset in terms of fostering dense social networks that can mitigate the risks of unemployment, it can also have positive potential in terms of fostering openness to experimentation. Michael explained:

[Interviewer]: So if I just try to understand what you're getting at-the idea is maybe in a larger city, there might... there may be so many more things available to you. If you really like something, you can go and slot yourself into it.

Michael: Yes.

[Interviewer]: Whereas here, it may or may not be present, so you might experiment by going to see something that you wouldn't necessarily...

Michael: Yeah, and you get dragged along with a friend, whatever; and I think you're less able to sort of really focus in on a certain thing and define yourself in that way, and to sort of snub everything else, right? In big cities there's, “Oh, I only go see like, you know, vegan, straight-edge bands" or something. I mean, you can't do that here, right? You either go see bands or you don't, basically. So I think, because of the amount of things happening and the amount of styles happening... people just are maybe more open to new things.

This link between small city size and openness to experimentation that Michael highlights is important to analyze because it suggests a different way to conceptualize assumed relationships between city size and creativity. From Michael's perspective, larger cities present increased opportunities for specialization and the hyper refinement of musical tastes-as his half-joking description of 'vegan straight-edge bands' sug- gests. Implicit here is the idea that the numerous opportunities for specialization and refinement that larger metropolitan centres offer can be barriers to experimentation because they allow people to remain within the envelope of their own proclivities. Smaller centres, because they offer fewer choices (e.g., in terms of styles of musical performances), might encourage a greater willingness to try experiences outside of one's comfort zone, that is, a greater willingness to experiment.

However, being in a small city is not always positive. As Sarah points out, the relatively small size of St. John's and its disconnectedness from other major urban areas plays a direct role in the lack of paid employment security in the film industry: 'There's not a lot of security in terms of constant work, and there's not a lot of guarantees that making your own work is going to make you any money at all. In fact, there's very little guarantee that it will. [I]t's not like, you know, Vancouver or Toronto or Montréal where there's production after production'. On the one hand, St. John's small size is perceived to foster a close-knit creative community and a culture of volunteerism that help overcome the risks of sporadic employment in creative industries. Creative workers in the industry are willing to help one another out in ways they might not be in larger centres like Toronto, Vancouver and Montréal where steadier employment in an industry such as film is more likely. On the other hand, it is the lack of steady work in film that makes filmmaking a challenge for people in the industry like Sarah and Jason-and one of the important factors impinging on their future career aspirations, a topic to which we now turn.

Michael, Sarah and Jason each grapple with aspects of their future career aspirations that would push and/or pull them away from St. John's. Michael, lead singer of an award-winning band, experiences external pressure to leave St. John's for Toronto and must balance this with the wishes of his fellow band members who want to remain in St. John's:

[W]e had a bit of pressure to move away, from our booking agent, who lives in Toronto. He could get us a lot of bookings if we were in Toronto because we could just go anywhere in the GTA (Greater Toronto Area) for the weekend, and Ontario-just so many people there, it's incredible; but, instead,

The Canadian Geographer / Le Géographe canadien 54, no 3 (2010) 
we have to go up there and sort of slog away for a month straight and then come home. ${ }^{4}$

From an economic standpoint, a large city like Toronto has obvious appeal for a group of musicians who must contend with building an audience who will support their work and the less glamorous aspects of the business such as the costs of travelling from gig-to-gig. A large city offers a larger actual and potential audience and more venues in a compact area.

Yet, Michael and his fellow band members are starting to see the kind of success that means they both can, and must, contemplate tour schedules that will exceed any single city. This possibility of major success-something new for Michael and the band-is opening new opportunities and constraints for where he wants to, and can, locate:

But we found that it doesn't really matter where you are ... because none of us will move to Toronto, so it's not really an option. Thinking about moving to Montréal or Halifax or Québec City or something, but it's still the same thing. I mean, eventually, it's not just going to be GTA that you're touring, so you're going to have to be away all the time anyway, so it doesn't really matter where you're based if you're never there, right?

Michael's response here suggests that industry type and stage of career are important to consider in creative class theory's assumptions about creatives' locational decisions (cf. Hansen and Niedomysl 2009). The industry and stage of career that Michael and his band find themselves in bears strongly on the kinds of locational choices that they see open to them.

\footnotetext{
${ }^{4}$ It is an eight-hour drive from St. John's to Corner Brook, the province's next largest city. The St. John's airport was the 11th busiest in the country in 2008 in terms of passenger traffic (Statistics Canada 2009b), but few direct connections with Canada's largest cities exist, except for Toronto, Montréal and Ottawa. Flying time to Halifax is about 1.5 hours, about 2.5 hours to Montréal and about 3 hours to Toronto. Flying to Vancouver from St. John's usually means connecting flights making cross-country travel a 12-18-hour trip. In 2006, St. John's lost direct air connection to Europe when Air Canada ceased its thrice weekly connection to London, Heathrow (CBC News 2008). Before the cancellation of St. John's Heathrow connection, it was a 4.5-hour flight to London. Air fares between St. John's and Canada's major cities often equal or exceed fares between those cities and major European or Asian destinations.
}

The realities of major tours will mean lengthy national and, possibly, international travel that takes them away from wherever their home base is. In this sense, where they are based does not matter. The corollary of this situation is a certain kind of support for the Florida hypothesis: Michael and his band have a certain freedom to choose to live wherever they wish. For Michael and his fellow creatives in the band, this means that 'we've all sort of, I think, agree(d) that we're going to live here. [chuckles] Our bass player refuses to even discuss the option of not living here. He's pretty tied to the place. And it seems like the older I get the more I feel the same way'.

For Jason and Sarah, the situation is somewhat different in terms of their future career aspirations. They both see themselves moving away from St. John's-at least temporarily-in order to pursue their craft as filmmakers. Sarah feels a certain loyalty to St. John's and its film community, but also has a personal preference for large cities: 'I don't want to abandon St. John's, by any means [but] I like Montréal and I like Toronto and so just personally, I see myself, needing to leave this place for awhile, even just to kind of get more creative inspiration'. But, beyond these personal preferences for large cities, Sarah pointed to city size (specifically the perceived smallness of St. John's) as a factor that bears on filmmaking as a craft. She cannot foresee making all her work in St. John's because there is 'a really small pool of actors here'. She also notes what she sees as important limitations related to Newfoundland landscapes in that 'there's a really small pool of places here where you can shoot that don't look like Newfoundland... every film I've ever written, nothing has been set in Newfoundland ...'. More important for Sarah, however, is that there is a need for change,

[to] work with different people to get better... this place doesn't have a lot of people. It doesn't have a lot of different people here... I can't imagine myself staying here permanently from here until the end of my life. [chuckles] I'm going to go for awhile, which doesn't mean I won't come back, which doesn't mean I don't want to come back.

In this part of Sarah's interview, the same characteristics of city size that she perceived as positive-a small city with strong, dense networks of support-are stifling her creative 
learning and growth. There is even a hint at the issue of a lack of diversity apparent in her description of a lack of 'different people here'. These various aspects of St. John's relatively small size are factors influencing Sarah's intention to move away from the city and the province, at least temporarily. In this sense, we can see some support for the creative class hypothesis that talent is attracted to open and diverse urban regions. However, this support for the creative class hypothesis is tempered by the positive aspects of St. John's small size described by Sarah and other interviewees. In the preceding examples, we also see the productive dimensions of place highlighted and how they can differ between industries (Storper and Scott 2009). A relatively small city-region can support the growth of a thriving independent music scene, but for filmmakers, St. John's lacks important factors for their development such as a large pool of actors and landscapes.

Like Sarah, Michael and Jason think seriously of leaving St. John's for career-related reasons. For Michael, this possibility is in constant fluctuation as he negotiates his own desires and career aspirations with those of his band members. But if he were to move, Michael sees several alternative places that would better suit his creative proclivities and offer more career-related opportunities than St. John's:

I'd like to live in Halifax because I have a lot of friends there, and I really, really love the music scene there, and it's also really close to home. I'd really love to live in Québec City just because it's like three times the size of St. John's and everywhere looks like downtown [chuckles] and everyone speaks French. I lived in Montréal for three years, and obviously miss that. There's so much going on there. I'd have a hard time picking one [of those three places].

When asked about what made his three alternative choices more attractive than St. John's, Michael focused on Québec City and Montréal. What appears important for him are certain tangible and intangible aspects of these cities-their larger size and greater connectedness to other centres in terms of relative location coupled to their perceived openness to creative endeavours and practices associated with ideas of 'Frenchness' (e.g., afternoon wine drinking).
Jason, unlike Michael but echoing Sarah, is very certain he will leave St. John's in the next three years. He will most likely move to Toronto 'because there is a larger market for selling my work and sustaining a long career [...] I think it's more difficult to do consistently here, whereas I think there's much broader markets and outputs in Toronto that would make that city attractive .... Jason, like Michael, recognizes certain tradeoffs in terms of quality of life between Toronto and St. John's, but for Jason these trade offs

would depend on what stage in your life you are in. I mean, if you are younger and you are feeling more mobile and you just wanted to work, I think it could be good. You know, and when it comes to the air quality, the amount of space you have for your property, the safety, security of your kidsthose are things that are great about St. John's in a lot of ways.

Similarly, Sarah said she would ideally like to live in large cities because of the economic opportunity and creative inspiration they offer her. If she were to move

[i]n Canada, it would have to be between Montréal, Vancouver and Toronto-Montréal being my first choice. You know, I'd love to live in New York. If there was any way I could work there or afford to live there, I'd love that. [...] There's definitely more opportunity work-wise in bigger cities, but I just think... I would find a lot more inspiration creatively from big cities, simply because there's more stuff to look at and learn and talk to and watch, you know.

Jason's and Michael's talk about their perceptions of links between St. John's and creativity resonated with Sarah's. For example, when asked about whether there are particular aspects of St. John's that enhance his creativity, Jason told us, 'I don't think so'. When asked the same question, Michael felt similarly: 'as much as I'd like, you know, your findings to be that, like, places really make creativity; and then like the government would be like-"oh, let's make this place sweet (so people) can be creative in (it)"-I think it's like... I don't know-you're kind of creative wherever you are, I think...'

Analyzing Sarah's, Jason's and Michael's interviews through the lens of creative class theory, we find some support for it, but there is a great 
deal more complexity than its tenets help us understand. To some extent, the world is, indeed, 'spiky' for these creatives (Florida 2008, 19; Martin and Florida 2009). Yet each of them finds aspects of St. John's relatively small size and location that help facilitate strong and dense social networks that help them achieve their goals as creative professionals. Moreover, loyalty to place-expressed overtly in Sarah's talk about not wanting to 'abandon' the city or in Michael's negotiations with his band mates-is playing at least some role in holding these creatives in place. The struggle of personal loyalties evident here suggests that the decisions of creative and highly educated workers to move, even at an age when mobility tends to be highest, involve more than looking elsewhere and answering 'What's there?' and 'Who's there?' (Florida 2002a) before making the choice to move. Our findings on this point strongly resonate with the results of Hansen and Niedomysl (2009), who find no evidence to support the supposition in creative class theory that members of this class are especially prone to mobility.

Moreover, another interviewee forced us to think more critically about the link between mobility and the subject-position pre-supposed in creative class theory. Karim, a naval architect in his early twenties, was born in Kenya and selfidentifies as Asian. When asked how likely it would be for him to move to another city-region, he related the following story:

I can't just move around like you. My friend said, "Hey, let's go to New York for a trip". Okay, that's great for them but if I want to go anywhere I have to get permission. You don't know how lucky you are to have a Canadian passport. If you go to Australia, that's great. If you go to the States, that's fine, you're one of them, if you go to the Middle East, they kiss your feet. I have to apply for a visa to go anywhere and then sometimes I get denied.

Yeah, that's not so bad (moving within Canada), but it's going back and forth outside of the country that is most difficult. I was going to an interview in Houston, everything was already set up, but my visa got denied so I couldn't go.

Karim raises an important issue that goes beyond differences in immigration policy between Canada and the US. Karim's narrative speaks to the subject-position assumed in creative class theory and its concerns about competition for talent. Creative class literature advocates the importance of tolerance and openness (Florida 2002a, 2005). Florida also argues that the similarities of the creative class are, 'determined by economic function-by the kind of work they do for a living. All other distinctions follow from that' (Florida 2002a, 8). However, the theory perhaps overstates the case that occupational identity is the fundamental determinant of members of the creative class's location decisions and mobility. What Karim's narrative suggests is that mobility is enabled to some extent by his credentials as a naval architect (thus making him a member of the supercreative core according to Florida 2002a) but his mobility is also constrained by issues of citizenship and of 'race' (Kobayashi and Peake 2000; Peake and Ray 2001) that mark him differently from other members of the creative class and impinge on his abilities to reap the supposed benefits of membership in that class. The strict occupational definition of the creative class ignores this kind of complexity and does not account for the issues of identity that clearly constrain the mobility Karim is supposed to have at his disposal as a member of the creative class. Creative class theory's emphasis on occupationally driven location choice and assumptions about the freedom to move misses the complex geometries of power that stratify labour flows (Massey 1994) thus enabling and constraining the mobility of differently situated members of this class through much finer grained sorting practices than occupational categories can account for in explaining the location patterns of members of the creative class. Karim's experience speaks to a missing component of creative class theory: a nuanced understanding of how the entwining of power and identity both enable and constrain the geographies of flows that sort members of this class into their variegated agglomerations.

\section{Employers and intermediary organizations}

From the perspective of employers and intermediary organizations, three key themes emerged in interviews: (1) St. John's small size and remoteness; (2) structural aspects of the labour market related to taxes and salaries and (3) social 
divides between Newfoundlanders as 'insiders' and those 'from away' as 'outsiders'. In broad terms, St. John's size and relative location were seen as significant challenges for getting and keeping creative and highly educated workers in St. John's, and the province more generally. For example, when asked about particular strengths and weaknesses of St. John's for attracting and retaining talent, Jacinta, a human resources manager in higher-education, replied, 'I think one of our strengths is also one of our weaknesses, which is our location, being located fairly remotely from everything else within Canada'. This sentiment about location was echoed in all of our other interviews as well. For example, Lawrence, the director of a health research organization, told us: 'This is a small place on the edge of the continent. There aren't a lot of jobs kicking around, but, when there are, it's often hard to find good talent. So you run an ad and get one or two applicants. It really is a problem, and the more specialized you get, the harder it is'. Jacinta reiterated this point about distance and disconnectedness: 'There's a big psychological barrier whenever you cross a body of water, so it's not as if you're moving from Ontario to Québec. You know, you're moving from Ontario to a place that's very far away. So the distance is certainly a factor'. Echoing the perceptions of creative workers like Michael, Jason and Sarah, both Jacinta and Lawrence speak to the issue of the relative size and location of St. John's from the perspective of an employer and intermediary organization, respectively. Jacinta describes the 'remoteness' of St. John's in relation to interprovincial/national urban places. Lawrence, on the other hand, places the city-region on the edge of a continental geographic imaginary, suggesting a set of international relations between St. John's and places elsewhere. In their different descriptions of 'remoteness' we see the fluid, yet stubbornly material, emplacement of St. John's on the margins.

Concomitant with perceptions about St. John's small size and disconnectedness, Lawrence pointed out structural aspects of the labour market as challenges to attracting and retaining creative and highly educated workers. As he said, 'there are not many jobs' and this can make it difficult to attract and retain talent who have partners and/or families. Related aspects of the labour market were also raised by Jacinta such as tax rates and salaries:

One of our challenges, in recruiting any type of an employee new to the market is our tax system because we do have the highest provincial tax rate, anywhere in Canada. So even if we are bringing someone from the west ... and we're able to match their salary, their take-home pay is not going to be the same because of our tax rate. ${ }^{5}$

Lawrence pointed to similar problems with salary structure when asked about facilitating attraction, retention and integration:

One of the challenges and obstacles is how pathetic the non-academic salaries are. Academic salaries here are not good, but they're not awful. The non-academic salaries really are not adequate. You can barely pay people. Even though the cost of living here is significantly lower than a lot of places, we really aren't paying people enough in jobs like program coordinator, research program manager, database manager, to bring people in and keep them here. They will come here (but) they never come here for the salaries.

The issue of salaries and wages as a particular challenge for attracting and retaining highly educated and creative workers to St. John's was raised repeatedly by participants. Brenda, a manager in the Provincial Government's Department of Business, put it this way:

The lure of the west (of Canada) and the money that's out there ... I think our biggest challenge is attracting and keeping ... the young people, because it's a brain drain. It's good to lose them for awhile provided we're able to get them back, and that we can have sufficient labour supply, skilled labour supply to move our businesses forward and position ourselves to be competitive with the rest of... well, not just the nation, but I think a... a lot of countries in the western hemisphere.

Responding to questions about challenges for attracting and retaining talent in St. John's and

\footnotetext{
${ }^{5}$ The issue of tax rates raises important issues of perceived versus actual rates. Jacinta's characterization of Newfoundland having the highest tax rates in Canada is correct up to and including 2006. However, after 2006, Newfoundland's provincial tax rates were reduced, which put the province's highest tax bracket in fourth place in 2007 and fifth place in 2008 and 2009 (Canada Revenue Agency 2009).
} 
Newfoundland more broadly, Richard, general manager of an offshore petroleum engineering firm, said, 'I think competitive salary is the biggest (challenge)' and Mark, vice president of a bank, pointed out. 'We are always challenged by the issue of compensation. People always like to earn more money'. Ron, president of a trade association, added: '[S]omebody who is trained perhaps in a skilled area ... can look elsewhere, not just Alberta, but look at Ontario or British Columbia or somewhere else if they're prepared to move, and find salaries and promotional opportunities that go far beyond what our employers can offer here'. Similarly, Laura, who runs an environmental consulting firm, was comparing the attractiveness of other cities and said, '[I]t would be Calgary and, to a lesser extent, Fort McMurray. It's just sort of the mystique that's grown up around it and people, you know, are drawn by the energy-just the excitement of being part of a really big project. That's very seductive, and also the thought of these high salaries'. While Jane, a board member of a trade association, pointed out that,

Other things, I suppose, would attract workers from around the world would be wages and, you know, if we can't meet some of the wages that are being paid in the rest of Canada, i.e. [sic] Alberta, then I don't think we're going to attract Newfoundlanders who are in Alberta back home simply because I don't think... people, once they are used to a salary, are not going to take a major cut.

The emphasis on salaries and wages that emerged in our interviews is important. Creative class theory does not argue that amenities are a perfect substitute for wages and employment. Yet, it does claim that a key shift has occurred: firms and jobs are locating, relocating or being created where the talent is, rather than people following firms and jobs (Florida 2002a). However, this claim remains a disputed proposition in the literature (Asheim and Hansen 2009; Boschma and Fritsch 2009; Hansen and Niedomysl 2009; Storper and Scott 2009). We think it important that when responding to interview questions about the principal challenges facing St. John's, all employer and intermediary organization participants highlighted money, rather than amenities, as the key challenge for the attraction and retention of talent.
Another strong common, though complex, theme to arise concerns an insider/outsider dynamic between 'Newfoundlanders', 'mainlanders' and others from 'outside' Newfoundland. Both Jacinta and Lawrence spoke about this unprompted, though in slightly different ways. For Jacinta, who was born and raised in Newfoundland (though she has worked outside the province), it is a dual problem of stereotypes or assumptions held by 'outsiders' on the one hand and 'insiders' on the other that help create an us/them dynamic. This issue began to emerge in Jacinta's interview when she was asked about the city-region's strengths and weaknesses. She told us: 'I think our general reputation within the rest of Canada is probably a weakness. Until people actually experience us, I don't believe that mainland Canada fully appreciates how welleducated, how diverse, how culturally oriented this province is becoming'. Here the issue of 'outsider' stereotypes is rather subtle, but it was an issue that became more pronounced as Jacinta's interview continued. For example, when talking about what in St. John's undermines its attractiveness in terms of recruitment efforts, Jacinta answered in part:

We're still very much an insular community... Although we're very friendly, we're also very... I don't want to say suspicious, but whenever I sit down with anyone, I still get the-'Who's your father?' 'Where were you born?'-Right? [I]t's very important to find out how you're connected to Newfoundland, and I think that that can be a real barrier.

Jacinta uses the pronoun 'we' in reference to Newfoundlanders being 'insular', suggesting she understands herself as part of that inside group. She is from Newfoundland, but worked in Ontario for several years before returning. Her hesitancy at explaining the inside/outside dichotomy is revealing. It suggests a feeling with real consequences, but also one that is difficult to explain without reinforcing stereotypes that 'outsiders' may already have.

Lawrence, who self-identified as an 'outsider', was much more emphatic:

Well, frankly, there's a problem. There's a CFA [Come From Away] problem. I'm one of them. Many academics who come here from elsewhere 
in Canada or elsewhere, find that the only people they end up hanging around with are other CFA's, whether Canadian or not. So, unless you have some structural grounds for breaking through that barrier, you often don't.

That there is a well-known acronym for this phenomenon, 'CFA' or 'Come From Away'-an acronym that Lawrence saw no need to spell out for the interviewer, whom he had just metis suggestive of the extent to which this kind of division is felt as a genuine emotional facet of daily life and that plays an important role in its spacing and timing (Jones et al. 2004). The CFA/Newfoundlander division points to a complex set of historical-geographical lineaments that crystallize contemporary St. John's as a place shot through with uneven social geographies of power and identity. In certain ways, the divide also speaks directly to the characteristics of tolerance and openness that creative class theory posits as important for the economic success of particular places.

Such a divide presents policy challenges. The provincial government and civil society organizations are actively involved in policy implementation to overcome such divides and increase the attraction and retention rates of highly educated and creative workers. Key policies and programs include the province's new immigration strategy that seeks to create 'welcoming communities' that respect diversity and make newcomers feel 'at home' (Government of Newfoundland and Labrador 2007, 7). The strategy aims to attract 1,200-1,500 immigrants annually and increase retention rates from the current estimate of 36 percent to between 60 and 80 percent (Government of Newfoundland and Labrador 2007). Key partners in the provincial immigration strategy include governmental (e.g., the Rural Secretariat) and nongovernmental organizations (e.g., the Association of New Canadians), educational institutions and business and labour organizations among others (Government of Newfoundland and Labrador 2007, 28-31). An assessment of these programs is beyond the scope of this article, but they are geared towards enhancing mutual understanding between Newfoundlanders and newcomers in ways that overcome the actual and perceived Newfoundlander/CFA divide.
Our findings suggest that a key factor in shaping the attraction and retention of creative and highly educated workers to St. John's is its relative size and location with respect to provincial, national and international urban systems. This metropolis on the margin exhibits 'large' city characteristics because of its size and functional role relative to the provincial urban system. On the other hand, the city-region's small size and isolation relative to larger, more connected national and international urban systems mitigates against its ability to attract and retain talent. The relatively small size of the city allows dense social networks and a culture of mutual support. People working in arts and culture activities benefit from these social supports during downturns, as they help them find alternative employment, and they value the distinct Newfoundland identity and the creativity of the local arts scene. Relative to larger arts and culture centres, such as Toronto, Montréal or even Halifax, however, they see St. John's as a staging ground to prepare for opportunities where there is greater diversity and demand for specialized skills. Employers and intermediaries also emphasize the role of St. John's relative size and location. To these factors they add the role of lower salaries, higher taxes and a divide that persists between Newfoundlanders and those from 'away'.

\section{Conclusions}

We have offered an examination of two linked hypotheses: that the social dynamics of cityregions constitute the foundations of economic success in the global economy; and, that talented, highly educated individuals will be attracted to those city-regions that offer a richness of employment opportunity, a high quality of life, a critical mass of cultural activity and social diversity. We have found a certain degree of support for these propositions, though with some caveats.

Social dynamics, in the form of strong and dense networks of employment and creative support, are emphasized as critically important by creative professionals to cope with the precarious nature of employment in their fields as well as to enhance the creativity of their work. In

The Canadian Geographer / Le Géographe canadien 54, no 3 (2010) 
the case of St. John's, the character and quality of these networks are enhanced by the relatively small size and disconnectedness of the city-region. However, these same characteristics appear to be problematic for creative workers as well as for employers and intermediaries. For home-grown talent, St. John's seems to be a staging ground before migration out of the province to pursue career aspirations, at least temporarily. We also have a sense that the attraction of home-grown talent to St. John's is, at least partially, a self-fulfilling process. St. John's is the province's metropole, making it almost inevitable that it exhibits metropolitan, or 'large' city, characteristics in a relatively small place. If talented individuals are attracted to places with the right mix of employment opportunities, quality of life, a critical mass of cultural activities and social diversity, then there are no other options in the province than St. John's. This is not to say that other communities in Newfoundland are lacking in all such characteristics, but it is in St. John's where such characteristics are most intensely articulated with one another in an urban place.

From the perspective of employers and intermediaries, St. John's relative size and location make attraction and retention of talent a distinct challenge. Perceptions of relatively low salaries and higher taxes are also seen as deterrents. But what also appears to be important is the persistence of an insider/outsider dynamic to the social relations of the city-region. The persistence of such a dynamic is seen to be a real barrier to integration that plays a distinctive role in retaining, if not attracting, creative and highly educated workers.

Our findings suggest the importance of how historical and geographical antecedents play a critical, but contingent-and we would argue, largely 'uncontrollable'-role in making places what they are in relation to other places. In Newfoundland, a staples economy remains of central importance. The diminished role of fisheries extraction is being followed by the growing importance of other extractive industries, especially oil and mining. The shift in staples production is part of the re-placement of the province's population and labour force. Within the province, we see a depopulation of the outport periphery coupled to political-economic centralizing tendencies in a few centres along a ribbon of national highway, while the province as a whole experiences significant net out-migration. These processes remind us that historical-geographic contingency and specificity matter and are conditioned by political, economic and cultural relations with places elsewhere.

The characteristics of city-regions need to be understood from a perspective that understands them as made through their connections to, and disconnections from, places elsewhere. The manner in which connection and disconnection are articulated in place make geographic specificity and contingency crucial analytics to take account of. The character of similarly sized city-regions will be conditioned by their emplacement and (dis)connectedness. For example, despite Kingston, Ontario being in the same absolute size class in the national ISRN study as St. John's, the former city-region's relative location with respect to three of Canada's largest cities (Toronto, Montréal and Ottawa) will make it a very different place from St. John's in terms of attracting and retaining talent. This observation is not some naïve geographical determinism. It is simply to say that city size and location, in both absolute and relative terms, matters. The presence of such qualities as 'diversity', 'cultural activities' and 'creative networks' are themselves 'relative' phenomena in St. John's-they are present here more than in Corner Brook, far more than in Burgeo, but less so than in Halifax or Montréal. Whether one sees St. John's as the 'bright lights, big city' or a 'provincial backwater', depends very much on the extent to which one is on, or of, the margins. These points speak to the attraction and retention of talent, but also to the question of insider/outsider dynamics, since diversity in its various incarnations may be measured and experienced differently in St. John's than in other urban, rural or outport communities provinciallyor in relation to other urban-regions nationally and internationally. The 'spikes' of the world are not heads of pins, but knots in threads of relational size and (dis)connection.

In terms of what lessons our findings may have for policy-makers, we contend that urban economic growth strategies premised on creative class theory seem to be of limited relevance for a city-region like St. John's. There 
are three main reasons for this. First, participants in our study did not emphasize the presence or absence of amenities as significant factors influencing the attraction and retention of highly educated and creative workers to St. John's. Rather than amenities being seen as a key driver of attraction and retention, it would seem that salaries and tax rates are perceived to be of much more importance. Second, qualities of place that do seem to matter, but in equally positive and negative ways, are the relative size and (dis)connection of St. John's within provincial, national and international networks of places. As Hansen and Niedomysl (2009) point out in their critique of creative class theory, it may be that the theory is relevant in countries like the US with many large urban centres from which members of the creative class can selectively choose. In countries like Canada where only a few large cities exist, the co-presence of the creative class in those city-regions with relatively higher levels of economic growth is a near certainty. In the Canadian context, as with the Swedish context studied by Hansen and Niedomysl (2009), it seems more likely that such co-presence represents a spurious correlation as opposed to a causal relationship between the presence of the creative class and high economic growth.

Third, St. John's is the metropole in the province in large part due to antecedent geographical and historical processes of urban economic growth that have been lately intensified by the transition to an economy heavily reliant on off-shore oil and gas development. The extant co-location in St. John's of the main infrastructure of provincial government institutions (and regional federal government institutions), the industrial infrastructure of the offshore oil and gas sector and Atlantic Canada's largest university strongly skew the urban hierarchy of the province towards St. John's. The geographical situation of St. John's coupled with the emphasis on salaries, wages and taxes in our interview material suggests that the specific geographies of production activities and work relevant for St. John's are more important drivers of the location decisions of highly educated and creative individuals than are the presence or absence of amenities.

\section{Acknowledgements}

The authors wish to acknowledge research funding provided by the Social Sciences and Humanities Research Council of Canada's Major Collaborative Research Initiative and the ISRN. We thank Charlie Conway for the preparation of the maps. We also thank Seamus Heffernan for invaluable editorial advice. Any shortcomings of the article remain the sole responsibility of the authors.

\section{References}

ASнввоок, т. 2009 America's Post-Crash Geography (National Public Radio) (Available at: http://www.onpointradio. org/shows/2009/02/americas-post-crash-geography/, accessed 2 April 2009)

ASHEIM, в. R., and HANSEN, H. G. к. 2009 'Knowledge bases, talents, and contexts: on the usefulness of the creative class approach in Sweden' Economic Geography 85(4), 425-442

BARNES, K., WAITT, G., NICHOLAS, G., and GIBSON, C. 2006 'Community and nostalgia in urban revitalisation: a critique of urban village and creative class strategies as remedies for social "problems"' Australian Geographer 37(3), 335354

BEUGELSDIJK, S. 2007 'Entrepreneurial culture, regional innovativeness and economic growth' Journal of Evolutionary Economics $17,187-210$

вOSCHMA, R. A., and FRाтSCH, м. 2009 'Creative class and regional growth: empirical evidence from seven European countries' Economic Geography 85(4), 391-423

BRIDGE, G. 2007 'A global gentrifier class?' Environment and Planning A 39, 32-46

BUNTING, T. Е. 2004 'Decentralization or recentralization? A question of household versus population enumeration, Canadian metropolitan areas 1971-1996' Environment and Planning A 36(1), 127-147

Bunting, T. E., and Filion, P. 2006 Canadian Cities in Transition: Local through Global Perspectives, (3rd ed.), (Don Mills, ON: Oxford University Press)

CANADA REVENUE AGENCY. 2009 What Are the Income Tax Rates in Canada for 2009? (Available at: http://www.craarc.gc.ca/tx/ndvdls/fq/txrts-eng.html, accessed 7 April 2009)

CBC NEws. 2008 St. John's Travellers Cross Fingers for French Connection (Available at: http://www.cbc.ca/consumer/ story/2008/01/09/french-connection.html, accessed 15 April 2008)

CLIFTON, N. 2008 'The "creative class" in the UK: an initial analysis' Geografiska Annaler Series B-Human Geography 90B(1), 63-82

CRANG, M., and СOок, I. 2007 Doing Ethnographies (Los Angeles, CA: Sage)

CURRID, E. 2006 'New York as a global creative hub: a competitive analysis of four theories on world cities' Economic Development Quarterly 20(4), 330-350

DANYLUK, M., and LEY, D. 2007 'Modalities of the new middle class: ideology and behaviour in the journey to work from gentrified neighbourhoods in Canada' Urban Studies 44(11), 2195-2210 
DELLER, S. C., TSAI, T.-H., MARCOUILLER, D. W., and ENGLISH, D. B. K. 2001 'The role of amenities and quality of life in rural economic growth' American Journal of Agricultural Economics 83(2), 352365

DOLOREUX, D., and DIONNE, S. 2008 'Is regional innovation system development possible in peripheral regions? Some evidence from the case of La Pocatière, Canada' Entrepreneurship \& Regional Development 20(3), 259-283

DONALD, B., and morrow, D. 2003 Competing for Talent: Implications for Social and Cultural Policy in Canadian City-Regions (Ottawa: Strategic Research and Analysis, Canadian Heritage)

DONEGAN, M., and LOWE, N. 2008 'Inequality in the creative city: is there still a place for 'old-fashioned' institutions?' Economic Development Quarterly 22(1), 46-62

FERGUSON, M., ALI, K., OLFERT, M. R., and PARTRIDGE, M. 2007 'Voting with their feet: jobs versus amenities' Growth and Change 38(1), $77-110$

FLORIDA, R. 2002a The Rise of the Creative Class and How It's Transforming Work, Leisure, Community, and Everyday Life (New York: Basic Books)

-. 2002b 'The economic geography of talent' Annals of the Association of American Geographers 92(4), 743755

-. 2002c 'Bohemia and economic geography' Journal of Economic Geography 2(1), 55-71

-. 2003 'Cities and the creative class' City \& Community 2(1), 3-19

-. 2005 The Flight of the Creative Class: The New Global Competition for Talent (1st ed.), (New York: HarperBusiness)

-. 2008 'Megaregions: the importance of place' Harvard Business Review 86(3), 18-19

-. 2009 'How the crash will reshape America' Atlantic Magazine March (Available at: http://www.theatlantic. com/doc/200903/meltdown-geography, accessed 2 April 2009)

FLORIDA, R., MELLANDER, C., and STOLARICK, K. 2008 'Inside the black box of regional development-human capital, the creative class and tolerance' Journal of Economic Geography 8(5), 615649

FLORIDA, R., STOLARICK, K., and MELlander, c. 2010 'Talent, technology and tolerance in Canadian regional development' The Canadian Geographer, Early View 14 March (doi: 10.1111/j.1541-0064.2009.00293.x)

GERTLER, M. S. 2001 'Urban economy and society in Canada: flows of people, capital and ideas' Isuma: The Canadian Journal of Policy Research 2(3), 119-130

-. 2003 'Tacit knowledge and the economic geography of context, or the undefinable tacitness of being (there)' Journal of Economic Geography 3(1), 75-99

GOVERNMENT OF NEWFOUNDLAND AND LABRADOR. 2007 Diversity- 'Opportunity and Growth': An Immigration Strategy for Newfoundland and Labrador (St. John's: Office of Immigration and Multiculturalism) (Available at: http://www.nlimmigration.ca/media/2842/strategydocmar07.pdf, accessed 27 March 2010)

HANSEN, H. K., and NIEDOMYSL, T. 2009 'Migration of the creative class: evidence from Sweden' Journal of Economic Geography 9(2), 191-206

hill STRATEGIES. 2005 Artists by Neighbourhood in Canada (Available at: http://www.hillstrategies.com/creativity.php, accessed 7 April 2008)
INNIS, H. A. 1940 The Cod Fisheries: The History of an International Economy (New Haven, CT: Carnegie Endowment for International Peace, Division of Economics and History)

INNOVATION SYSTEMS RESEARCH NETWORK. 2008 Welcome (Available at: http://www.utoronto.ca/isrn/, accessed 13 June 2008)

JOHNSTONE, H., and LIONAIS, D. 2004 'Depleted communities and community business entrepreneurship: revaluing space through place' Entrepreneurship \& Regional Development 16(3), 217-233

Jones, G., MCleAn, C., and QUATTRONE, P. 2004 'Spacing and timing' Organization 11(6), 723-741

KOBAYASHI, A., and PEAKE, L. 2000 'Racism out of place: thoughts on whiteness and an antiracist geography in the new millennium' Annals of the Association of American Geographers 90(2), 392-403

LLOYD, R. 2002 'Neo-bohemia: art and neighborhood redevelopment in Chicago' Journal of Urban Affairs 24(5), 517-532

-. 2004 'The neighborhood in cultural production: material and symbolic resources in the new bohemia' City \& Community 3(4), 343-372

LOCKE, w. 2007 'Offshore oil and gas: is Newfoundland and Labrador getting its fair share?' Newfoundland Quarterly 99(3), 8-12

LORENZEN, M., and ANDERSEN, K. v. 2009 'Centrality and creativity: does Richard Florida's creative class offer new insights into urban hierarchy?' Economic Geography 85(4), 363390

MARKUSEN, A. 1999 'Sticky places in slippery space: a typology of industrial districts' in The New Industrial Geography: Regions, Regulations and Institutions, eds. T. J. Barnes and M. S. Gertler (London: Routledge), 98-124

-. 2006 'Urban development and the politics of a creative class: evidence from a study of artists' Environment and Planning A 38, 1921-1940

martin, R. L., and FloRIDA, R. 2009 Ontario in the Creative Age (Toronto: Martin Prosperity Institute)

MASSEY, D. 1994 Space, Place, and Gender (Minneapolis, MN: University of Minnesota Press)

mCCANN, E. J. 2007 'Inequality and politics in the creative cityregion: questions of livability and state strategy' International Journal of Urban and Regional Research 31(1), 188196

MCGRANAHAN, D., and WOJAN, T. 2007 'Recasting the creative class to examine growth processes in rural and urban counties' $R e$ gional Studies 41(2), 197-216

PEAKE, L., and RAY, B. 2001 'Racializing the Canadian landscape: whiteness, uneven geographies and social justice' The Canadian Geographer 45(1), 180-186

PECK, J. 2005 'Struggling with the creative class' International Journal of Urban and Regional Research 29(4), 740770

RANTISI, N. M., and LESLIE, D. 2006 'Branding the design metropole: the case of Montréal, Canada' Area 38(4), 364376

RANTISI, N. M., LESLIE, D., and CHRISTOPHERSON S. 2006 'Placing the creative economy: scale, politics, and the material-the rise of the new "creative" imperative' Environment and Planning A $38(10), 1789-1797$

ROY, N., ARNASON, R., and SCHRANK, W. E. 2006 The Fishery as Economic Base in the Newfoundland Economy. Paper presented to the International Institute of Fisheries Economics and Trade, Thirteenth International Conference 2006, Portsmouth 
(Available at: http://www.ucs.mun.ca/ñoelroy/20.pdf, accessed 24 April 2008)

SANDS, G., and REESE, L. A. 2008 'Cultivating the creative class: and what about Nanaimo?' Economic Development Quarterly 22(1), 8-23

schimpF, м. 2008 Creative Input: The Role of Culture Occupations in the Economy During the 1990s. Culture, Tourism and the Centre for Education Statistics Research Paper 81-595M-No. 064 (Ottawa: Statistics Canada)

SCHIMPF, M., and SEREDA, P. 2001 Towards a Geography of Culture: Culture Occupations across the Canadian Urban-Rural Divide. Culture, Tourism and the Centre for Education Statistics Research Paper 81-595-MIE-No. 053 (Ottawa: Statistics Canada)

sсотт, A. J. 2006 'Creative cities: conceptual issues and policy questions' Journal of Urban Affairs 28(1), 1-17

SIMms, A. 2009 'Functional Regions and the Regional Capacity Index' Presentation to the Federal Regional Council, St. John's, 29 January

SMITH, H. L., GLASSON, J., and CHADWICK, A. 2005 'The geography of talent: entrepreneurship and local economic development in Oxfordshire' Entrepreneurship \& Regional Development 17(6), 449-478

SPENCER, G., and VINODRAI, T. 2006 'Innovation Systems Research Network City-Region Profile: St. John's' Program on Globalization and Regional Innovation Systems (PROGRIS), 113

—. 2009 'Innovation Systems Research Network City-Region Profile: St. John's (Update)' Program on Globalization and Regional Innovation Systems (PROGRIS) 1-13

Stantec. 2009 Socio-Economic Benefits from Petroleum Industry Activity in Newfoundland and Labrador, 2005-2007. Final Report for Petroleum Research Atlantic Canada (Available at: http://pr-ac.ca/files/FinalReports/MP08-01_NL_ BenefitsUpdate.pdf, accessed 26 March 2010)

statistics canada. 2009a Table 3. Population of Census Metropolitan Areas in 2006 (Ottawa: Statistics Canada) (Available at: http://www12.statcan.ca/census-recensement/2006/assa/97-550/table/t3-eng.cfm, accessed 23 November 2009)

-. 2009b Table 1-1 Passengers Enplaned and Deplaned on Selected Service-Top 50 Airports (Ottawa: Statistics
Canada) (Available at: http://www.statcan.gc.ca/pub/51203-x/2008000/t008-eng.htm, accessed 20 March 2010) STOLARICK, K., and FLORIDA, R. 2006 'Creativity, connections and innovation: a study of linkages in the Montréal Region' Environment and Planning A 38(10), 1799-1817

STORPER, м., and MANVILLE, м. 2006 'Behaviour, preferences and cities: urban theory and urban resurgence' Urban Studies 43(8), 1247-1274

STORPER, M., and SCOTT, A. J. 2009 'Rethinking human capital, creativity and urban growth' Journal of Economic Geography 9(2), 147-167

SUMmERS, v. A. 2001 'Newfoundland: resource politics and regime change in the federal era, 1949-1991' in The Provincial State: Politics in Canada's Provinces and Territories, eds. K. Brownsley and M. Howlett (Peterborough, ON: Broadview Press), 23-48

THOMAS, J. M., and DARNTON, J. 2006 'Social diversity and economic development in the metropolis' Journal of Planning Literature 21(2), 153-169

UNITED STATES CENSUS BUREAU. 2009 Annual Estimate of the Population of Metropolitan and Micropolitan Statistical Areas: April, 2000 to July 1, 2008 (Available at: http://www.census.gov/popest/metro/tables/2008/CBSAEST2008-01.csv, accessed 23 November 2009)

WERNERHEIM, C. M., and SHARPE, C. A. 2006 'The rural/urban location pattern of advance services in an international perspective' in Services Industries and the Knowledge-Based Economy, eds. R. G. Lipsey and A. Nakamura (Calgary: University of Calgary Press), 445-490

WOJAN, T. R., LAMBERT, D. M., and MCGRANAHAN, D. A. 2007 'Emoting with their feet: Bohemian attraction to creative milieu' Journal of Economic Geography 7(6), 711-736

WOLFE, D. A. 2006 Social dynamics of economic performance: social sciences and humanities research council. Copy available from the author

WOLFE, D. A., and GERTLER, M. S. 2004 'Clusters from the inside and out: local dynamics and global linkages' Urban Studies 41(5-6), 1071-1093

WONG, K. w., and BUNNELL, т. 2006 “"New economy" discourse and spaces in Singapore: a case study of one-north' Environment and Planning A 38, 69-83 